Supplemental Material for

\title{
Anger Framed: A Field Study on Emotion, Pleasure, and Art
}

by

Valentin Wagner, Julian Klein, Julian Hanich, Mira Shah, Winfried Menninghaus, \& Thomas Jacobsen

\section{S1 Details on Participants and Procedure}

Participants - further group differences

Participants in the art-framing group were on average younger than in the assessmentframing group, 29.8 years vs. 33.4 years, respectively, $t(77)=2.01, p<.05$. The groups also differed regarding the following variables: (a) the time of day they were tested, $\chi^{2}=31.3, d f=2$, $p<.001$, with more participants in the assessment-framing group tested during the day and more in the art-framing group tested in the evening; (b) the Extraversion and Openness dimensions of the NEO-FFI, $t(74)=-2.34, p<.05 ; t(74)=-3.26, p<.01$, with higher values for the participants of the art-framing group on both dimensions (2.57 vs. 2.30 and 3.19 vs. 2.85 , respectively); (c) their motivations for solving the tasks, $\chi^{2}=10.6, d f=1, p<.01$, and sincerity in answering the scales, $\chi^{2}=9.16, d f=1, p<.01$, with more participants in the assessment-framing group motivated to solve the tasks and rating the scales sincerely; (d) their preferences for visiting theater plays and performances, $\chi^{2}=12.5, d f=4, p<.05$, with more participants in the art-framing group visiting modern theater more often; (e) understanding the tasks and comments, $\chi^{2}=4.16, d f=1, p<.05$, with more participants in the art-framing group experiencing problems in understanding (21\% in the art-framing group vs. $7 \%$ in the assessment-framing group); (f) 
alcohol consumed, $\chi^{2}=16.0, d f=2, p<.001$, with more participants in the art-framing group having consumed alcohol before the testing/play.

\section{Procedure - details}

At the time of their appointment, the theater visitors (art-framing group) were individually escorted to the suite of rooms by BrainCheck staff. In the front of the reception area, the participants were handed over to the receptionist. The participants in the assessment-framing group, on the other hand, received the address of the offices along with their appointment. They were informed that Ominura Solutions currently needed to operate in interim facilities due to construction work in their main offices. Professional signage guided them to the testing facility. At the time of their appointment, they came directly to the reception room.

The reception room served two purposes. First, it functioned as a waiting room and hence as a temporal buffer. Second, it helped to obscure which kind of framing treatment the participant received (that is whether the participant was a test volunteer or a theater visitor) and hence to "blind" the experimenters and performers to the participant's group membership. From this point onward all participants, regardless of their framing group, underwent an identical fully staged one-on-one performance. At the appointed time, the receptionist led the participant into the anteroom, where an experimenter/performer professionally greeted and briefed the participants. They were informed that a 20-EUR bonus awaited them if they performed excellently in the subsequent cognitive aptitude testing. An adequate and careful instruction was followed by the first administration of the PANAS, the SAM, and a blood pressure recording [TP1].

Next, the participant was escorted to one of the two testing rooms where the treatment was carried out. Here one of the two alleged testing assistants, both played by professional actors, took over. (We had two alleged testing assistants and testing rooms in order to be able to test up 
to 100 participants during the four days of the festival.) The testing assistants generally acted abusively and in a depreciating manner, gradually increasing the intensity of anger induction with different methods. Over the course of 20 minutes, seven (cognitive) performance tasks were administered to flesh out the cover story of a cognitive aptitude test and to engage the participants. Unsolvable or stupid tasks as well as inadequate feedback were also used to induce anger. The entire process was based on a fixed text and fully staged. Every comment and feedback was scripted and therefore independent of the participant's actual behavior and performance in the test. The manner of direction and rehearsing assured that the treatment led to a similar atmosphere to the utmost degree possible.

Theater production. The complete performance (Ominura Solutions/BrainCheck) was carefully directed. Care was taken that the tasks were new, unfamiliar, and challenging as well as humorous and entertaining to the participants. In preparation, we conducted a screening of the psychological literature for different anger-induction settings, using the publications listed in the online supplemental material S3 (Literature on Real-life Anger Induction). We employed a potpourri of anger-induction methods of the frustration and harassment variety found in this research.

In three weeks (21 days) of rehearsals, we produced a theater piece with a duration of 60 minutes and a cast of nine performers (two at the theater foyer welcome desk, one in the reception area, two for the anteroom procedure, two for the main treatment, and two for debriefing). A professional theater team consisting of a director, a stage designer, a production manager, and two assistants led the rehearsals and the entire production. During the production process, the rehearsal phases were always followed by test performances with members of the faculty's staff who were not involved in the study attending as visitors. These "visitors" were 
informed either that they would attend a theater rehearsal or that they would attend a pre-test of a current study (according to the later framing conditions). During the last week before the experiment, we invited guests to the main and general rehearsals in the same way as the visitors to the experiment, and they provided additional feedback to the director in a second interview (six of these are reported in Klein, 2010). The complete script of the performance is available from the authors.

Stimuli. While continuing to speak on his cell phone, the testing assistant urged the participant to sit down. Seemingly talking to his wife, he mentioned in an indignant manner that he was at work and could not talk because he had to "get rid of one subject" ("Ich muss jetzt noch einen abfertigen"; cf. Everson, McKey, \& Lovallo, 1995). Rudely greeting the participant, he asked for name, age, gender, and occupation (and then made a pejorative comment about the latter). He told the participant that seven tasks would follow, in which a total of 100 points were achieved on average - the challenge would be to achieve 120 points.

Task 1 was a derivative of the classic Stroop task (1935). Participants received partially incorrect instructions, were interrupted, and received depreciatory, false comments and feedback. Task 2 was an association task introduced to the participants as a creativity test. They were shown eight partially provocative or politically incorrect postcard-sized pictures and asked to produce spontaneous associations. The testing assistant interrupted them several times and made false corrections. Task 3, labelled multi-tasking, was a combination of backward counting (from 1999 down by 41/2) and simultaneously cutting five-pointed stars from yellow paper sheets. Participants were interrupted several times during their backward counting and had to start all over again with an easier number, thus indicating that their performance was not sufficient. 
Again, participants were subjected to depreciating comments and false feedback. Then, the PANAS, SAM, blood pressure, and pulse rate measures were obtained for the second time [TP2]. Task 4 was introduced as a number of intelligence test items. Frustration was induced by time pressure and giving the items in oral rather than written form, which rendered them more difficult. One item did not have an unambiguous solution; for another, any given answer was judged correct; and one task was a memory challenge with a childish text. Staged (false) feedback was employed. The second part of Task 4 was introduced as "cross-modal priming." Participants were asked to repeat the sentence Ich bin böse (meaning "I am angry [at someone]" as well as "I am vicious") in a loud voice three times. Then they were asked to hum a melody and to give the title of the piece, followed by a nonverbal comment. Then another ambiguous categorization item followed. All the while, they received depreciating comments and false feedback. The third acquisition of PANAS and SAM measures followed [TP3]. At this point, we did not collect blood pressure and pulse rates because we replaced these measures with a fake infrared measurement of blood flow in the scalp. Participants were placed under an insulated helmet, which would serve the purpose of motivating the repeated instruction to speak up during Task 5. For the correct positioning of the device, the testing assistant disregarded personal space and etiquette. After measuring the participant's head perimeter, he stuck a transparent scale on the participant's forehead, stating that he wanted to measure the distance between the participant's eyes. He then marked two points above the eyes on the scale, accidentally slipping the pen onto the participant's skin, and he pretended to remove the stray ink with his saliva. Next, in Task 5, participants were told that their general education would be probed. They were asked to complete proverbs from probes, some of which were changed and thus unsolvable. The testing assistant again interrupted the participant, complaining that the participant was not cooperating, i.e., not sitting quietly and not speaking loudly enough. 
In Task 6, we used verbal working memory measures as suggested by Daneman and Carpenter (1980). Participants had to read aloud newly constructed sentences that were provocative and partly politically incorrect and to memorize the last word of each sentence. The testing assistant interrupted the participants, made disparaging comments, and provided negative feedback. Prior to the final task, participants were informed that they needed an additional 27 points to reach the level of 120 points and thus win the premium. In this way, they were indirectly told that only 7 additional points were required to attain the average achievement of 100 points, despite the frequent negative feedback. Task 7 employed two newly constructed mental exercise items. The second item was not solvable and was repeated, due to an apparent error on the part of the experimenter. Participants were informed that they had given incorrect answers and thus received zero points. A last question was asked in a seemingly generous way. The participant received negative feedback one last time and was told that she or he would not receive the bonus, which was the climax of the anger treatment. Then the PANAS and SAM were administered and blood pressure and pulse rate were measured [TP4].

At this point, participants were escorted to the debriefing room by one of the two researchers who carried out the debriefing. There was no break between the moment of entering the anteroom and the debriefing. Care was taken to ensure that the participants did not meet each other. 


\section{Appraisal-Questionnaire}

Bitte geben Sie an, wie sehr die folgenden Aussagen auf Sie zu treffen auf Skala von 1 für „stimme ich vollkommen zu“ bis 7 für „lehne ich vollkommen ab“ [Please indicate how much the following statements apply to you, with 1 standing for "I agree totally" and 7 for "I disagree totally"]. ${ }^{1}$

1. Ich hatte die Kontrolle darüber, was während der Situation passiert ist. control [I had control over what happened during the situation.]

2. Die Situation als solche (unabhängig von meinen eigenen Zielen) ist positiv zu bewerten. intrinsic pleasure [The situation as such (regardless of my own goals) is positive.]

3. Das was in der Situation passiert ist, hatte Konsequenzen für meine Ziele. goal conduciveness [What happened in the situation had consequences for my goals.]

4. Mein Abschneiden in den Aufgaben des Leistungstest ist mir wichtig gewesen. personal relevance [My performance in the tasks of the cognitive aptitude test has been important to me.]

5. Was während der Situation passiert ist, kam sehr unerwartet. unexpectedness [What happened during the situation was very unexpected.]

6. Ich bin in dem Erreichen meiner Ziele behindert worden. hindrance [I have been hindered in reaching my goals.]

7. Für das was während der Situation passiert ist, ist der Versuchsleiter verantwortlich. other-responsibility [For what has happened during the situation, the investigator is responsible.]

8. Ich hätte den Ausgang der Situation mehr beeinflussen können. self-responsibility/power [I could have influenced the outcome of the situation more strongly.]

\footnotetext{
${ }^{1}$ Please note, the ratings have been recoded thus that higher values represent approval and lower values disapproval.
} 


\section{References}

Daneman, M., \& Carpenter, P. A. (1980). Individual differences in working memory and reading. Journal of Verbal Learning and Verbal Behavior, 19, 450-466. doi: 10.1016/S00225371(80)90312-6

Everson, S. A., McKey, B. S., \& Lovallo, W. R. (1995). Effect of trait hostility on cardiovascular-responses to harassment in young men. International Journal of Behavioral Medicine, 2, 172-191. doi: 10.1207/s15327558ijbm0202_6

Klein, J. (2010). Emotionstheater?: Anmerkungen zum Spielgefühl. [Emotion theater?: Remarks on the feeling of playing]. Forum Modernes Theater, 25, 77-91. doi:

$10.1353 /$ fmt. 2010.0006

Stroop, J. R. (1935). Studies of interference in serial verbal reactions. Journal of Experimental Psychology, 18, 643-662. doi: 10.1037/h0054651 


\section{S2 Additional Analyses Including Covariates}

Table S2.1. Mixed model ANOVAs for the SAM scales

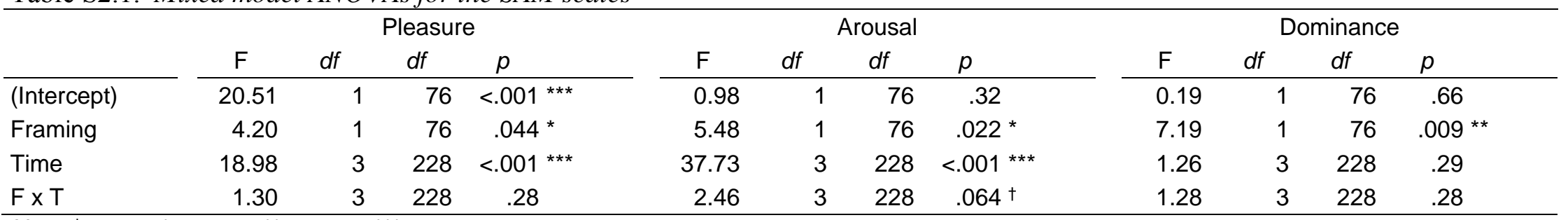

Note. ${ }^{\dagger} p<.1 ;{ }^{*} p<.05 ;{ }^{\star \star} p<.01,{ }^{\star \star \star} p<.001$.

Table S2.2. Mixed model ANOVAs for the SAM scales including covariates

\begin{tabular}{|c|c|c|c|c|c|c|c|c|c|c|c|c|}
\hline & \multicolumn{4}{|c|}{ Pleasure } & \multicolumn{4}{|c|}{ Arousal } & \multicolumn{4}{|c|}{ Dominance } \\
\hline & $\mathrm{F}$ & $d f$ & $d f$ & $p$ & $\mathrm{~F}$ & $d f$ & $d f$ & $p$ & $\mathrm{~F}$ & $d f$ & $d f$ & $p$ \\
\hline (Intercept) & 0.29 & 1 & 38 & .59 & 0.02 & 1 & 38 & .89 & 1.24 & 1 & 38 & .27 \\
\hline Framing & 5.63 & 1 & 38 & .023 * & 0.01 & 1 & 38 & .92 & 6.95 & 1 & 38 & .012 * \\
\hline Time & 12.57 & 3 & 156 & $<.001 * \star *$ & 27.39 & 3 & 156 & $<.001 * \star \star$ & 1.22 & 3 & 156 & .30 \\
\hline $\mathrm{F} \times \mathrm{T}$ & 0.38 & 3 & 156 & .77 & 1.75 & 3 & 156 & .16 & 0.44 & 3 & 156 & .72 \\
\hline Sex & 3.10 & 1 & 38 & $.086^{\dagger}$ & 1.65 & 1 & 38 & .21 & 0.92 & 1 & 38 & .34 \\
\hline Age & 0.05 & 1 & 38 & .83 & 0.97 & 1 & 38 & .33 & 2.16 & 1 & 38 & .15 \\
\hline $\begin{array}{l}\text { NEO-FFI } \\
\text { Extraversion }\end{array}$ & 0.18 & 1 & 38 & .67 & 0.24 & 1 & 38 & .62 & 0.29 & 1 & 38 & .59 \\
\hline $\begin{array}{l}\text { NEO-FFI } \\
\text { Openness }\end{array}$ & 2.64 & 1 & 38 & .11 & 1.94 & 1 & 38 & 0.17 & 2.64 & 1 & 38 & .11 \\
\hline $\begin{array}{l}\text { Experimental } \\
\text { experience }\end{array}$ & 0.13 & 1 & 38 & .72 & 0.07 & 1 & 38 & .79 & 0.07 & 1 & 38 & .80 \\
\hline Sincerity & 0.46 & 1 & 38 & .50 & 0.01 & 1 & 38 & .91 & 0.00 & 1 & 38 & .97 \\
\hline Motivation & 0.09 & 1 & 38 & .76 & 0.95 & 1 & 38 & .34 & 0.03 & 1 & 38 & .87 \\
\hline $\begin{array}{l}\text { Alcohol } \\
\text { consumption }\end{array}$ & 0.23 & 1 & 38 & .63 & 0.08 & 1 & 38 & .78 & 1.68 & 1 & 38 & .20 \\
\hline $\begin{array}{l}\text { Preference for } \\
\text { theater }\end{array}$ & 1.70 & 4 & 38 & .17 & 1.04 & 4 & 38 & .40 & 0.55 & 4 & 38 & .70 \\
\hline Understanding & 0.39 & 1 & 38 & .53 & 0.54 & 1 & 38 & .47 & 0.22 & 1 & 38 & .64 \\
\hline Credibility & 0.42 & 1 & 38 & .52 & 1.29 & 1 & 38 & .26 & 0.70 & 1 & 38 & .41 \\
\hline
\end{tabular}


Table S2.3. Mixed model ANOVAs for the PANAS

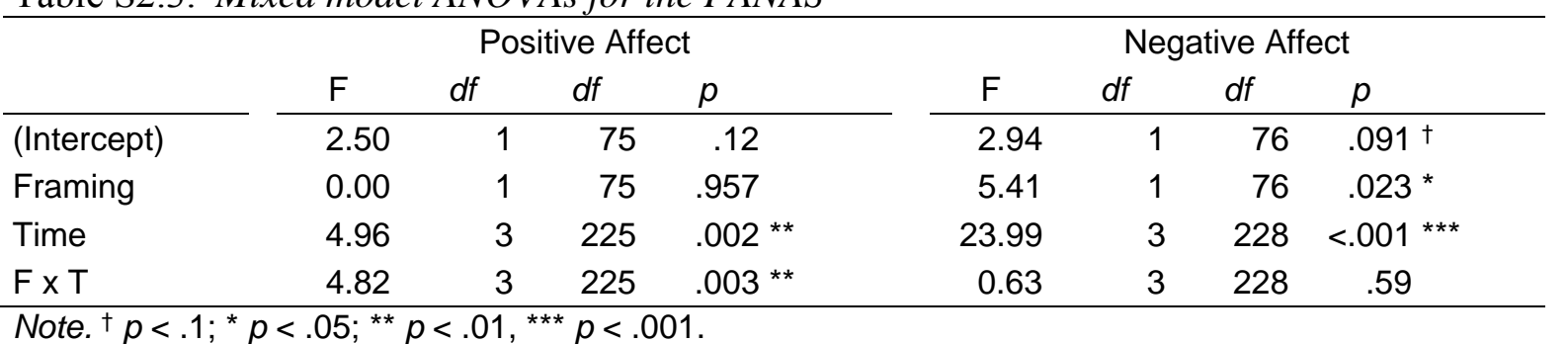

Table S2.4. Mixed model ANOVAs for the PANAS including covariates

\begin{tabular}{|c|c|c|c|c|c|c|c|c|}
\hline & \multicolumn{4}{|c|}{ Positive Affect } & \multicolumn{4}{|c|}{ Negative Affect } \\
\hline & $\mathrm{F}$ & $d f$ & $d f$ & $p$ & $\mathrm{~F}$ & $d f$ & $d f$ & $p$ \\
\hline (Intercept) & 0.35 & 1 & 38 & .56 & 0.96 & 1 & 38 & .33 \\
\hline Framing & 0.02 & 1 & 38 & .89 & 4.68 & 1 & 38 & .037 * \\
\hline Time & 2.58 & 3 & 156 & $.056^{\dagger}$ & 15.93 & 3 & 156 & $<.001 * \star \star$ \\
\hline $\mathrm{F} \times \mathrm{T}$ & 2.62 & 3 & 156 & $.053^{\dagger}$ & 0.12 & 3 & 156 & .95 \\
\hline Sex & 0.61 & 1 & 38 & .44 & 0.00 & 1 & 38 & .96 \\
\hline Age & 1.18 & 1 & 38 & .28 & 1.69 & 1 & 38 & .20 \\
\hline $\begin{array}{l}\text { NEO-FFI } \\
\text { Extraversion }\end{array}$ & 3.65 & 1 & 38 & .064 & 0.32 & 1 & 38 & .58 \\
\hline $\begin{array}{l}\text { NEO-FFI } \\
\text { Openness }\end{array}$ & 1.30 & 1 & 38 & .26 & 1.89 & 1 & 38 & .18 \\
\hline $\begin{array}{l}\text { Experimental } \\
\text { experience }\end{array}$ & 0.22 & 1 & 38 & .64 & 0.03 & 1 & 38 & .86 \\
\hline Sincerity & 0.17 & 1 & 38 & .68 & 0.72 & 1 & 38 & .40 \\
\hline Motivation & 0.17 & 1 & 38 & .68 & 4.22 & 1 & 38 & .047 * \\
\hline $\begin{array}{l}\text { Alcohol } \\
\text { consumption }\end{array}$ & 0.19 & 1 & 38 & .66 & 0.78 & 1 & 38 & .38 \\
\hline $\begin{array}{l}\text { Preference for } \\
\text { theater }\end{array}$ & 0.12 & 4 & 38 & .98 & 0.19 & 4 & 38 & .94 \\
\hline Understanding & 2.24 & 1 & 38 & .14 & 1.01 & 1 & 38 & .32 \\
\hline Credibility & 1.22 & 1 & 38 & .28 & 0.00 & 1 & 38 & .96 \\
\hline
\end{tabular}

Note. ${ }^{\dagger} p<.1 ;{ }^{\star} p<.05 ;{ }^{\star \star} p<.01,{ }^{\star \star \star} p<.001$. 
Table S2.5. Mixed model ANOVAs for the peripheral physiological measures

\begin{tabular}{|c|c|c|c|c|c|c|c|c|c|c|c|c|}
\hline & \multicolumn{4}{|c|}{ Systolic blood pressure } & \multicolumn{4}{|c|}{ Diastolic blood pressure } & \multicolumn{4}{|c|}{ Pulse } \\
\hline & $\mathrm{F}$ & $d f$ & $d f$ & $p$ & $\mathrm{~F}$ & $d f$ & $d f$ & $p$ & $\mathrm{~F}$ & $d f$ & $d f$ & $p$ \\
\hline (Intercept) & 0.86 & 1 & 74 & .36 & 27.64 & 1 & 74 & $<.001 * \star \star$ & 2.70 & 1 & 74 & .11 \\
\hline Framing & 7.34 & 1 & 74 & .008 ** & 3.44 & 1 & 74 & $.068^{\dagger}$ & 1.73 & 1 & 74 & .19 \\
\hline Time & 21.84 & 2 & 148 & $<.001 * \star \star$ & 10.75 & 2 & 148 & $<.001 * \star \star$ & 20.77 & 2 & 148 & $<.001 * \star \star$ \\
\hline $\mathrm{F} \times \mathrm{T}$ & 0.49 & 2 & 148 & 61 & 3.91 & 2 & 148 & .022 * & 2.62 & 2 & 148 & $.076^{\dagger}$ \\
\hline
\end{tabular}

Table S2.6. Mixed model ANOVAs for the peripheral physiological measures including covariates

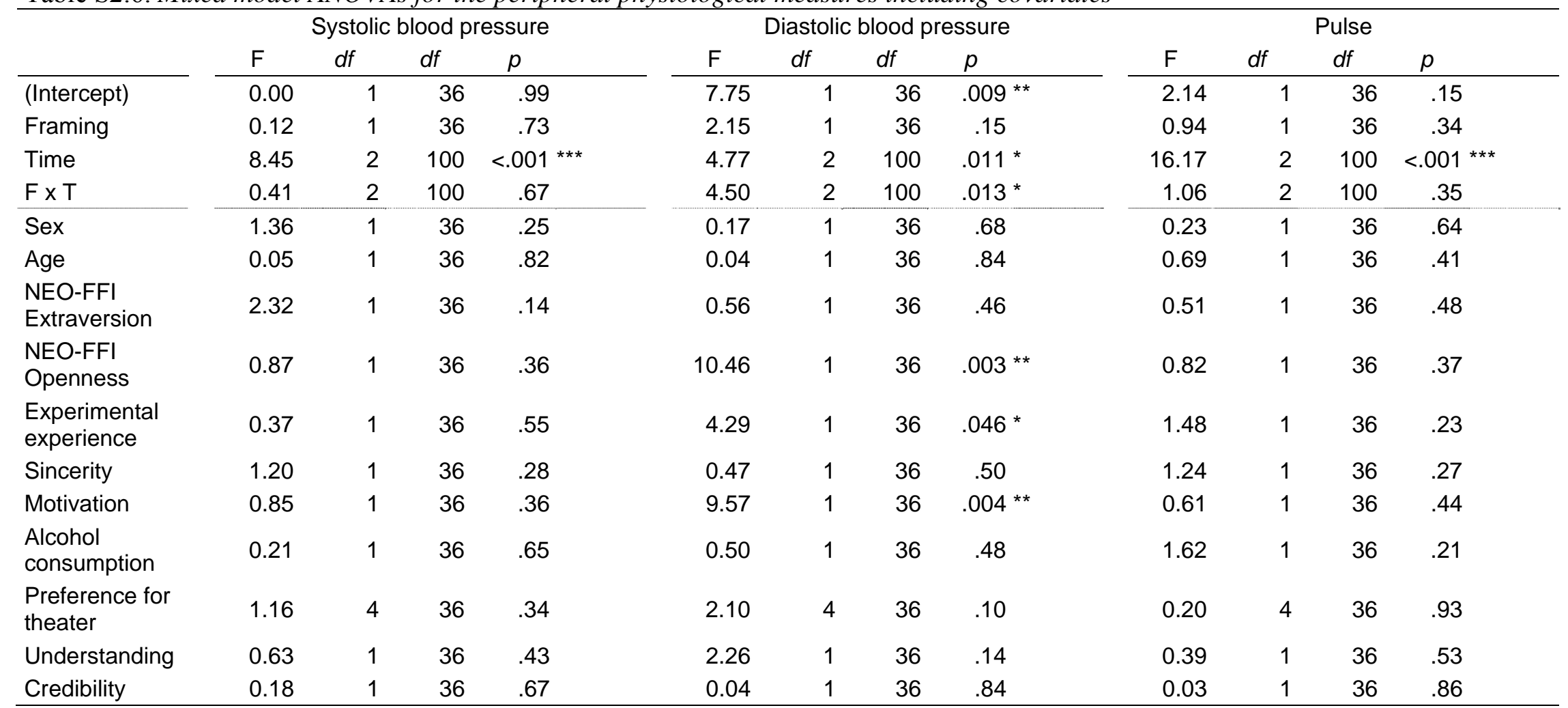

Note. ${ }^{\dagger} p<.1 ;{ }^{\star} p<.05 ;{ }^{\star \star} p<.01,{ }^{\star \star \star} p<.001$. 


\section{S3 Literature on Real-life Anger Induction}

Anderson, J. C., Linden, W., \& Habra, M. E. (2005). The importance of examining blood pressure reactivity and recovery in anger provocation research. International Journal of Psychophysiology, 57(3), 159-163. doi: 10.1016/j.ijpsycho.2004.12.011

Atkinson, C., \& Polivy, J. (1976). Effects of delay, attack, and retaliation on state depression and hostility. Journal of Abnormal Psychology, 85(6), 570-576.

Ax, A. F. (1953). The physiological differentiation between fear and anger in humans. Psychosomatic Medicine, 15(5), 433-442.

Bishop, G. D., \& Robinson, G. (2000). Anger, harassment, and cardiovascular reactivity among Chinese and Indian men in Singapore. Psychosomatic Medicine, 62(5), 684-692.

Böddeker, I., \& Stemmler, G. (2000). Who responds how and when to anger? The assessment of actual anger response styles and their relation to personality. Cognition \& Emotion, 14(6), 737-762.

Bongard, S., Pfeiffer, J. S., al'Absi, M., Hodapp, V., \& Linnenkemper, G. (1997). Cardiovascular responses during effortful active coping and acute experience of anger in women. Psychophysiology, 34(4), 459-466.

Bongard, S., \& Wilke, B. (2008). Methoden der kontrollierten Ärgerinduktion. Experimentelle Emotionspsychologie (pp. 333-345). Berlin: Pabst.

Buss, A. H. (1963). Physical aggression in relation to different frustrations. Journal of Abnormal Psychology, 67(1), 1-7.

Cohen, D., Bowdle, B. F., Nisbett, R. E., \& Schwarz, N. (1996). Insult, aggression, and the southern culture of honor: An "experimental ethnography". Journal of Personality and Social Psychology, $70(5), 945-960$.

Diamond, E. L., Schneiderman, N., Schwartz, D., Smith, J. C., Vorp, R., \& Pasin, R. D. (1984). Harassment, hostility, and Type-A as determinants of cardiovascular reactivity during competition. Journal of Behavioral Medicine, 7(2), 171-189. doi: 10.1007/Bf00845385 
Diamond, L. M., \& Hicks, A. M. (2005). Attachment style, current relationship security, and negative emotions: The mediating role of physiological regulation. Journal of Social and Personal Relationships, 22(4), 499-518. doi: 10.1177/0265407505054520

Drummond, P. D. (1999). Facial flushing during provocation in women. Psychophysiology, 36(3), 325332.

Earle, T. L., Linden, W., \& Wenberg, J. (1999). Differential effects of harassment on cardiovascular and salivary cortisol stress reactivity and recovery in women and men. Journal of Psychosomatic Research, 46(2), 125-141.

Eckhardt, C. I., \& Cohen, D. J. (1997). Attention to anger-relevant and irrelevant stimuli following naturalistic insult. Personality and Individual Differences, 23(4), 619-629. doi: 10.1016/S01918869(97)00074-3

Edguer, N., \& Janisse, M. P. (1994). Type-A behavior and aggression - provocation, conflict and cardiovascular responsivity in the Buss teacher-learner paradigm. Personality and Individual Differences, 17(3), 377-393. doi: 10.1016/0191-8869(94)90285-2

Engebretson, T. O., Matthews, K. A., \& Scheier, M. F. (1989). Relations between anger expression and cardiovascular reactivity - reconciling inconsistent findings through a matching hypothesis. Journal of Personality and Social Psychology, 57(3), 513-521. doi: 10.1037/0022-3514.57.3.513

Everson, S. A., McKey, B. S., \& Lovallo, W. R. (1995). Effect of trait hostility on cardiovascular responses to harassment in young men. International Journal of Behavioral Medicine, 2(2), 172 191. doi: 10.1207/s15327558ijbm0202_6

Felsten, G. (1995). Cynical hostility influences anger, but not cardiovascular reactivity during competition with harassment. International Journal of Psychophysiology, 19(3), 223-231.

Frodi, A. (1978). Experiential and physiological - responses associated with anger and aggression in women and men. Journal of Research in Personality, 12(3), 335-349. doi: 10.1016/00926566(78)90060-0

Garcia-Leon, A., del Paso, G. A. R., Robles, H., \& Vila, J. (2003). Relative effects of harassment, frustration, and task characteristics on cardiovascular reactivity. International Journal of Psychophysiology, 47(2), 159-173. doi: 10.1016/S0167-8760(02)00124-1 
Gilbert, S., \& Thompson, J. K. (1999). Winning or losing against an opposite-sex peer on a gender-based competitive task. Sex Roles, 41(11-12), 875-899. doi: 10.1023/A:1018884513692

Glynn, L. M., Christenfeld, N., \& Gerin, W. (2007). Recreating cardiovascular responses with rumination: The effects of a delay between harassment and its recall. International Journal of Psychophysiology, 66(2), 135-140. doi: 10.1016/j.ijpsycho.2007.03.018

Hernandez, D. H., Larkin, K. T., \& Whited, M. C. (2009). Cardiovascular response to interpersonal provocation and mental arithmetic among high and low hostile young adult males. Applied Psychophysiology and Biofeedback, 34(1), 27-35. doi: 10.1007/s10484-009-9076-3

Hokanson, J. E. (1961). Vascular and psychogalvanic effects of experimentally aroused anger. Journal of Personality, 29(1), 30-39.

Hokanson, J. E., \& Shelter, S. (1961). The effect of overt aggression on physiological arousal level. Journal of Abnormal and Social Psychology, 63(2), 446-448.

IJzerman, H., van Dijk, W. W., \& Gallucci, M. (2007). A bumpy train ride: A field experiment on insult, honor, and emotional reactions. Emotion, 7(4), 869-875. doi: 10.1037/1528-3542.7.4.869

Jäncke, L. (1996). Facial EMG in an anger-provoking situation: Individual differences in directing anger outwards or inwards. International Journal of Psychophysiology, 23(3), 207-214.

Janssen, S. A., Spinhoven, P., \& Brosschot, J. F. (2001). Experimentally induced anger, cardiovascular reactivity, and pain sensitivity. Journal of Psychosomatic Research, 51(3), 479-485.

Krieglmeyer, R., Wittstadt, D., \& Strack, F. (2009). How attribution influences aggression: Answers to an old question by using an implicit measure of anger. Journal of Experimental Social Psychology, 45(2), 379-385. doi: 10.1016/j.jesp.2008.10.003

Lai, J. Y., \& Linden, W. (1992). Gender, anger expression style, and opportunity for anger release determine cardiovascular reaction to and recovery from anger provocation. Psychosomatic Medicine, 54(3), 297-310.

Lavoie, K. L., Miller, S. B., Conway, M., \& Fleet, R. P. (2001). Anger, negative emotions, and cardiovascular reactivity during interpersonal conflict in women. Journal of Psychosomatic Research, 51(3), 503-512. 
Lobbestael, J., Arntz, A., \& Wiers, R. W. (2008). How to push someone's buttons: A comparison of four anger-induction methods. Cognition \& Emotion, 22(2), 353-373. doi: $10.1080 / 02699930701438285$

Mauss, I. B., Butler, E. A., Roberts, N. A., \& Chu, A. (2010). Emotion control values and responding to an anger provocation in Asian-American and European-American individuals. Cognition \& Emotion, 24(6), 1026-1043. doi: 10.1080/02699930903122273

Mauss, I. B., Cook, C. L., Cheng, J. Y. J., \& Gross, J. J. (2007). Individual differences in cognitive reappraisal: Experiential and physiological responses to an anger provocation. International Journal of Psychophysiology, 66(2), 116-124. doi: 10.1016/j.ijpsycho.2007.03.017

Mauss, I. B., Cook, C. L., \& Gross, J. J. (2007). Automatic emotion regulation during anger provocation. Journal of Experimental Social Psychology, 43(5), 698-711. doi: 10.1016/j.jesp.2006.07.003

Polivy, J. (1981). On the induction of emotion in the laboratory - discrete moods or multiple affect states. Journal of Personality and Social Psychology, 41(4), 803-817.

Schachter, J. (1957). Pain, fear, and anger in hypertensives and normotensives - a psychophysiological study. Psychosomatic Medicine, 19(1), 17-29.

Schachter, S., \& Singer, J. E. (1962). Cognitive, social, and physiological determinants of emotional state. Psychological Review, 69(5), 379-399.

Siegman, A. W., Anderson, R., Herbst, J., Boyle, S., \& Wilkinson, J. (1992). Dimensions of angerhostility and cardiovascular reactivity in provoked and angered men. Journal of Behavioral Medicine, 15(3), 257-272.

Stemmler, G. (1989). The autonomic differentiation of emotions revisited: Convergent and discriminant validation. Psychophysiology, 26(6), 617-632.

Stemmler, G. (1997). Selective activation of traits: Boundary conditions for the activation of anger. Personality and Individual Differences, 22(2), 213-233. doi: 10.1016/S0191-8869(96)00189-4

Stemmler, G. (2008). Induktion von Emotionen in der experimentellen Emotionspsychologie. In W. Janke (Ed.), Experimentelle Emotionspsychologie (pp. 207-224). Berlin: Pabst. 
Stemmler, G., Heldmann, M., Pauls, C. A., \& Scherer, T. (2001). Constraints for emotion specificity in fear and anger: The context counts. Psychophysiology, 38(2), 275-291.

Suarez, E. C., Harlan, E., Peoples, M. C., \& Williams, R. B. (1993). Cardiovascular and emotional responses in women - the role of hostility and harassment. Health Psychology, 12(6), 459-468.

Suarez, E. C., \& Williams, R. B. (1989). Situational determinants of cardiovascular and emotional reactivity in high and low hostile men. Psychosomatic Medicine, 51(4), 404-418.

Suchday, S., Carter, M. M., Ewart, C. K., Larkin, K. T., \& Desiderato, O. (2004). Anger cognitions and cardiovascular recovery following provocation. Journal of Behavioral Medicine, 27(4), 319-341.

Suchday, S., \& Larkin, K. T. (2004). Psychophysiological responses to anger provocation among Asian Indian and white men. International Journal of Behavioral Medicine, 11(2), 71-80. doi: 10.1207/s15327558ijbm1102_2

Van Goozen, S. H. M., Frijda, N. H., Wiegant, V. M., Endert, E., \& Van de Poll, N. E. (1996). The premenstrual phase and reactions to aversive events: A study of hormonal influences on emotionality. Psychoneuroendocrinology, 21(5), 479-497. doi: 10.1016/0306-4530(95)00022-4

Vella, E. J., \& Friedman, B. H. (2009). Hostility and anger in: Cardiovascular reactivity and recovery to mental arithmetic stress. International Journal of Psychophysiology, 72(3), 253-259. doi: 10.1016/j.ijpsycho.2009.01.003

Ward, A., Mann, T., Westling, E. H., Creswell, J. D., Ebert, J. P., \& Wallaert, M. (2008). Stepping up the pressure: Arousal can be associated with a reduction in male aggression. Aggressive Behavior, 34(6), 584-592. doi: 10.1002/Ab.20270 